\title{
Mobile Learning (M-Learning) Based Learning Application Design for Elementary School Students
}

\author{
Nadya Verona Viani Kamasi ${ }^{1}$, Tirsa Julianti Saruan ${ }^{1)}$ \\ 1) Jurusan Teknik Komputer, Universitas Sariputra Indonesia Tomohon \\ nay.public@gmail.com
}

(Article History： Received 04-02-2020; Accepted 06-06-2020; Published 15-06-2020)

\begin{abstract}
This study was designed to produce a learning design based on Mobile Learning (M-Learning) that is appropriate for elementary school students. In making this instructional media design, the Multimedia Development Life Cycle (MDLC) method consists of six stages: concept, design, obtaining material, assembly, testing, and distribution, but in this study only carried out two stages, concept and design. The results showed that the MDLC method privides the feasibility percentage of: media experts amounted to $89.44 \%$; material experts amounted to $92,89 \%$, and teachers amounted to $93.3 \%$. This study produces a learning design based on Mobile Learning (M-Learning) that is feasible to be applied for elementary school students.
\end{abstract}

Keywords: Learning media; mobile learning; multimedia development life cycle

\section{Desain Aplikasi Pembelajaran Berbasis Mobile Learning (M-Learning) Untuk Siswa Sekolah Dasar}

\begin{abstract}
ABSTRAK
Penelitian ini bertujuan untuk menghasilkan desain media pembelajaran berbasis Mobile Learning (M-Learning) yang layak untuk siswa sekolah dasar. Dalam membuat desain media pembelajaran ini digunakan metode Multimedia Development Life Cycle (MDLC) yang terdiri dari enam tahapan yaitu concept, design, obtaining content material, assembly, testing, dan distribution, namun pada penelitian ini hanya dilakukan dua tahapan saja yaitu tahap concept dan tahap design. Hasil penelitian menunjukkan bahwa metode MDLC memberikan hasil persetase kelayakan dari: ahli media sebesar 89,44\%; ahli materi sebesar 92,89\%; dan guru-guru sebesar 93,3\%. Penelitian ini menghasilkan sebuah desain media pembelajaran berbasis Mobile Learning (M-Learning) yang layak diterapkan pada siswa sekolah dasar.
\end{abstract}

Kata Kunci: Media pembelajaran; mobile learning; multimedia development life cycle

\section{PENDAHULUAN}

Teknologi menjadi salah satu pioner pendidikan karena telah berdampak pada kualitas dan kuantitas pengajaran, pembelajaran, dan penelitian di institusi pendidikan tradisional dan jarak jauh (Yusuf, 2005). Terlebih penerapan teknologi pembelajaran yang fleksibel dapat mendorong siswa untuk memperoleh suatu keterampilan. Seiring berkembangnya dunia teknologi, terjadi lonjakan global dalam hal penggunaan perangkat mobile, khususnya handphone. Hal ini juga terjadi di dunia pendidikan. Pengembangan pembelajaran dengan memanfaatkan media berbasis teknologi genggam dan bergerak (mobile) atau saat ini lebih dikenal dengan mobile learning menjanjikan independensi waktu dan tempat dalam arti sesungguhnya. Penggunaan mobile learning juga membantu meningkatkan motivasi belajar siswa. (Sonego, et al., 2016)

Terdapat sugesti belajar yang besar saat menggunakan handphone karena handphone memudahkan, mendukung, meningkatkan dan memperluas jangkauan pengajaran dan pembelajaran. Potensi yang besar dapat dihasilkan jika sumber dan strategi belajar dikelola dengan benar menggunakan M-Learning. Siswa juga bisa merasakan efektivitas pembelajaran yang 
besar jika menggunakan M-Learning dibandingkan dengan pembelajaran saat ini (Donnell \& Donnell, 2014).

Selain itu, perangkat mobile sudah banyak digunakan di kalangan siswa. Perangkat mobile yang digunakan dalam mobile learning antara lain adalah PDA, handphone, dan tablet. Karakteristik perangkat mobile ini memiliki tingkat fleksibilitas dan portabilitas yang tinggi sehingga memungkinkan siswa dapat mengakses materi, video tutorial dan praktikum secara virtual yang berkaitan dengan pembelajaran kapanpun dan di manapun. Hal ini akan meningkatkan minat dan perhatian siswa pada materi pembelajaran (Yuniati, 2012).

Namun tak jarang, handphone yang dimiliki siswa hanya digunakan untuk bermain game saja. Bahkan menurut Munir (2013) banyak waktu pelajar yang terbuang karena kecenderungan memakai dan memainkan handphone setiap waktu. Akibatnya hal-hal lain yang menyangkut pelajaran tersisihkan bahkan waktu belajar juga tidak jarang dipakai untuk memainkan handphone. Seharusnya handphone digunakan untuk hal-hal yang lebih positif. Oleh karena itu, perlu dibuat desain suatu aplikasi pembelajaran berbasis mobile learning untuk siswa sekolah dasar yang dapat memaksimalkan penggunaan handphone.

Penelitian ini bertujuan untuk mengembangkan media pembelajaran berbasis mobile learning untuk Siswa Sekolah Dasar.

\section{METODE PENELITIAN}

Model penelitian yang digunakan adalah Multimedia Development Life Cycle (MDLC). Model Multimedia Development Life Cycle atau MDLC terdiri dari enam tahapan, yaitu Concept, Design, Obtaining Content Material, Assembly, Testing, dan Distribution. Gambaran tahapan dapat dilihat di gambar 1 (Munir, 2013)

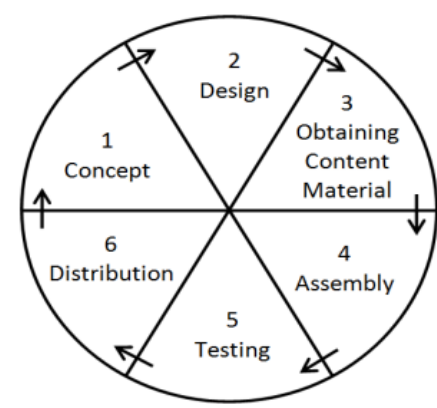

Gambar 1. Tahapan Multimedia Development Life Cycle

\section{Concept}

Tahapan pengonsepan yaitu menentukan tujuan dan siapa pengguna program (identifikasi audience), macam aplikasi (presentasi, interaktif, dan lain-lain), tujuan aplikasi (informasi, hiburan, pelatihan, dan lain-lain), dan spesifikasi umum. Dasar aturan untuk perancangan juga ditentukan pada tahap ini, seperti ukuran aplikasi, target, dan lain-lain. Tujuan dan pengguna akhir program berpengaruh pada nuansa multimedia sebagai pencerminan dari identitas organisasi yang menginginkan informasi sampai pada pengguna akhir. Karakteristik pengguna termasuk kemampuan pengguna juga perlu dipertimbangkan karena dapat mempengaruhi pembuatan desain.

\section{Design}

Pada tahap ini pembuatan spesifikasi mengenai arsitektur program, gaya, tampilan, dan kebutuhan material/bahan untuk program. Meskipun demikian, pada praktiknya, pengerjaan projek pada tahap awal masih akan sering mengalami penambahan bahan atau pengurangan bagian aplikasi, atau perubahan-perubahan lain.

\section{Obtaining Content Material}

Tahap ini adalah tahap pengumpulan bahan yang sesuai dengan kebutuhan yang dikerjakan. Bahan-bahan tersebut, antara lain gambar clip art, foto, animasi, video, audio, dan bahan lainnya yang akan digunakan. Tahap ini dapat dikerjakan secara paralel dengan tahap assembly. Namun, pada beberapa kasus, tahap obtaining content material dan tahap assembly akan dikerjakan secara linear dan tidak paralel. 


\section{Assembly}

Secara lebih rinci, kegiatan-kegiatan yang dilakukan pada tahap pembuatan adalah sebagai berikut:

1) Menyiapkan teks tentang materi untuk keseluruhan pembuatan produk.

2) Menggabungkan bagian-bagian materi yang telah terkumpul pada tahapan Obtaining Content Material.

3) Membuat program sesuai dengan paduan storyboard yang telah dibuat sebelumnya. Semua bagian materi yang telah dikumpulkan kemudian digabungkan menjadi satu produk yang kemudian akan direvisi lagi.

\section{Testing}

Menurut (Rosa \& Shalahuddin, 2015), pengujian perangkat lunak adalah sebuah elemen topik yang memiliki cakupan luas dan sering dikaitkan dengan verifikasi (verification) dan validasi (validation) (V\&V). Verifikasi adalah sekumpulan tugas yang memastikan bahwa perangkat lunak benar menerapkan fungsi yang ditentukan, sedangkan validasi adalah sekumpulan tugas yang berbeda yang memastikan bahwa perangkat lunak yang telah dikembangkan sesuai dengan persyaratan pengguna (Pressman, 2001).

\section{Distribution}

Pada tahap ini, aplikasi yang telah dikembangkan digandakan dan diberikan ke pengguna untuk digunakan. Distribusi dapat dalam berbagai bentuk, baik untuk presentasi proyektor, maupun dalam bentuk CD-ROM, perangkat mobile, dan situs web.

\section{HASIL DAN PEMBAHASAN}

Pembuatan desain media pembelajaran menggunakan metode Multimedia Development Life Cycle (MDLC) yang terdiri dari enam tahapan. Tapi pada penelitian ini hanya dua tahapan awal yang akan dilakukan yaitu tahap concept dan tahap design.

\section{Concept}

Tahap ini merupakan tahapan awal yang dilakukan dalam penelitian ini, pada tahap ini dilakukan perencanaan awal untuk pembuatan desain media pembelajaran berbasis mobile learning. Kegiatan yang dilakukan adalah: a) Penentuan Tujuan

Tujuan pembuatan desain aplikasi ini yaitu untuk aplikasi pembelajaran yang berfokus pada siswa kelas 4 dengan materi tumbuhan dan hewan. Pada aplikasi akan disediakan materi pengenalan tumbuhan dan hewan dalam bentuk gambar yang menarik dan juga video agar anak-anak lebih antusias dalam proses pembelajaran.

b) Melakukan wawancara kepada guru yang mengajar juga kepala sekolah untuk menentukan jenis aplikasi

Berdasarkan hasil wawancara dan survey awal pengguna produk maka produk ini adalah untuk menghasilkan desain media pembelajaran berbasis mobile learning yang layak digunakan dan bermanfaat dalam proses pembelajaran.

c) Penentuan Spesifikasi Umum Aplikasi

Desain aplikasi yang dibuat adalah untuk aplikasi berbasis mobile learning yang diakses menggunakan smartphone berbasis android dengan spesifikasi sebagai berikut:

$\checkmark$ Sistem operasi android minimal versi Android 4.0 Ice Cream Sandwich

$\checkmark$ RAM minimal 512 megabyte.

$\checkmark$ Ukuran aplikasi maksimal 300 megabyte

$\checkmark$ Aplikasi pembelajaran bisa menyesuaikan dengan berbagai ukuran layar handphone.

$\checkmark$ Warna yang digunakan adalah perpaduan warna cerah yaitu warna putih untuk background, warna biru dan merah untuk tombol dan shapes, dan warna hitam untuk tulisan. Selain perpaduan warna, digunakan juga perpaduan animasi bergerak yang berhubungan dengan hewan dan tumbuhan untuk menarik minat siswa.

\section{Design}

Pada tahap ini pembuatan spesifikasi mengenai arsitektur program, gaya, tampilan, dan kebutuhan material/bahan untuk program. Spesifikasi dibuat serinci mungkin sehingga pada tahap berikutnya, yaitu obtaining content material dan assembly, pengambilan keputusan baru tidak diperlukan lagi, cukup menggunakan keputusan yang sudah ditentukan pada tahap ini. Kegiatan yang dilakukan meliputi:

a) Penentuan Materi

Kegiatan ini meliputi penentuan materi yang akan dimuat dalam media pembelajaran 
berbasis mobile learning yang akan dikembangkan. Materi pembelajaran yang akan dimuat adalah materi pengenalan tumbuhan dan hewan.

b) Penentuan Arsitektur Aplikasi

Arsitektur aplikasi pembelajaran berbasis M-Learning digambarkan seperti pada Gambar 2.

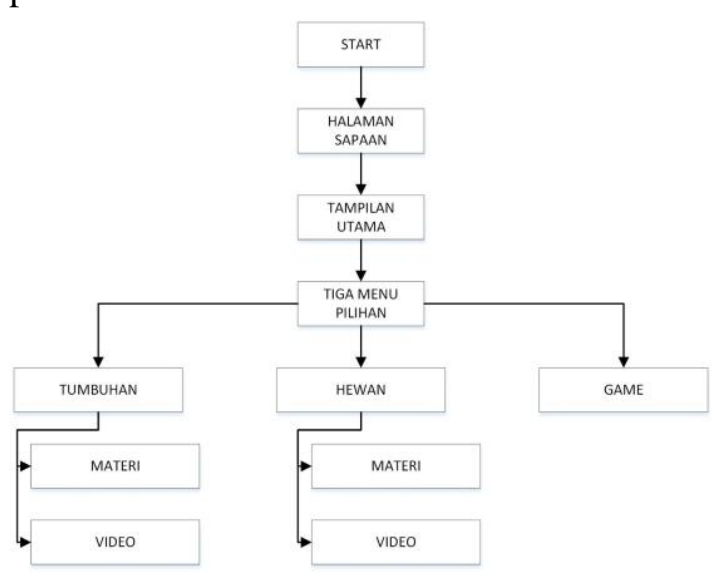

Gambar 2. Arsitektur Aplikasi

c) Penentuan Gaya Aplikasi

Aplikasi pembelajaran ini adalah aplikasi yang mudah digunakan untuk anak sekolah dasar dengan mempertimbangkan kemudahan akses tombol, tampilan menarik, penyajian materi yang mudah dipahami karena menyertakan gambar-gambar dan video serta animasi-animasi yang sesuai dengan tema pembelajaran.

d) Pembuatan Desain Produk

Kegiatan pembuatan desain produk terlebih dahulu dibuat alur program seperti pada gambar 3. Kemudian pembuatan flowchart yang digambarkan pada gambar 4, yang mengambarkan alur media pembelajaran berbasis mobile learning dan bertujuan untuk mengatur tiap halaman yang akan dibuat. Selanjutnya membuat storyboard yang menggambarkan secara keseluruhan gambaran produk yang akan dibuat seperti yang ada pada gambar 5 sampai gambar 11.

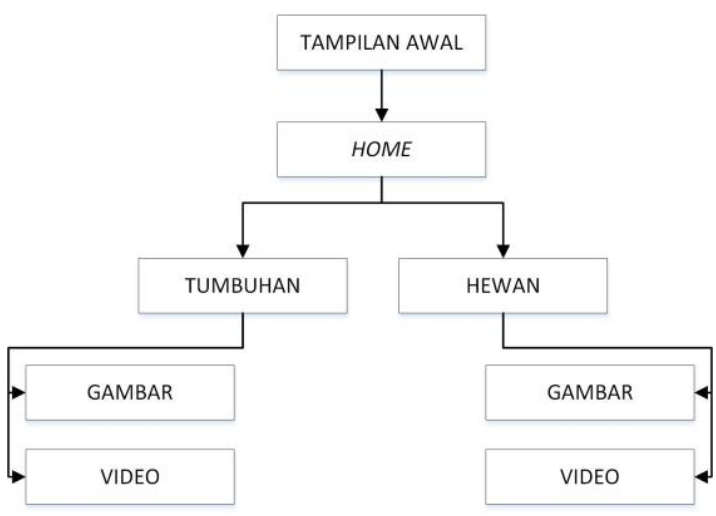

Gambar 3. Alur Program

Setelah pembuatan alur program, maka akan dibuat flowchart untuk aplikasi pembelajaran ini seperti yang terlihat di gambar 4.

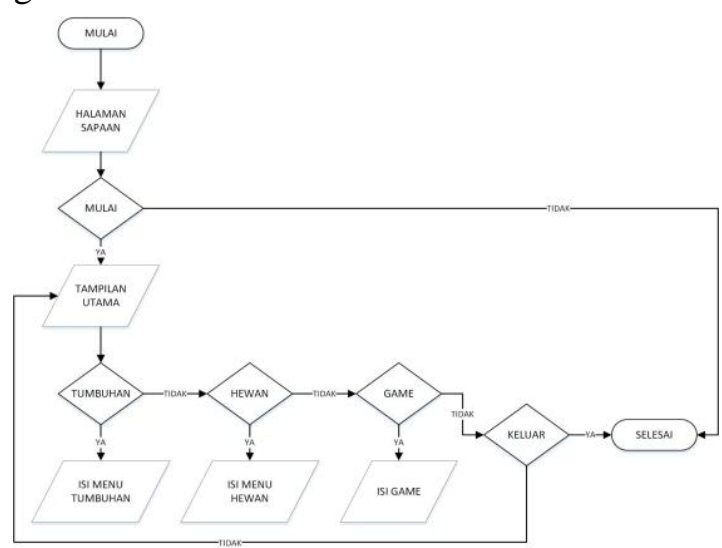

Gambar 4. Flowchart Aplikasi

Setelah flowchart selesai dibuat, hal selanjutnya yang dilakukan adalah pembuatan storyboard. Berikut adalah storyboard dari desain aplikasi pembelajaran ini

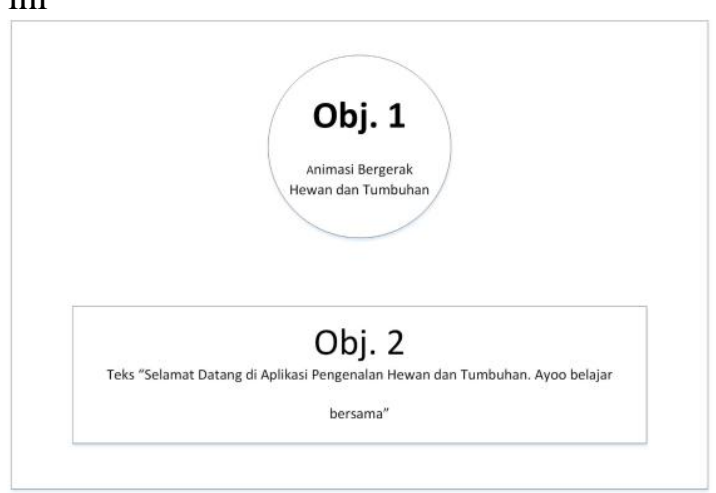

Gambar 5. Tampilan Sapaan 


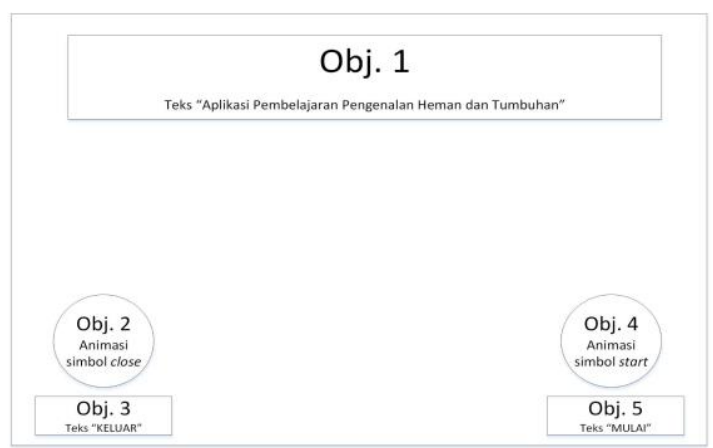

Gambar 6. Tampilan Awal

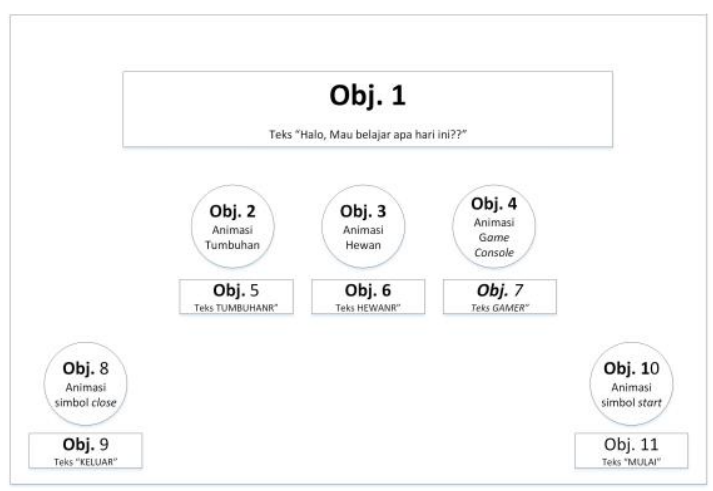

Gambar 7. Tampilan Menu

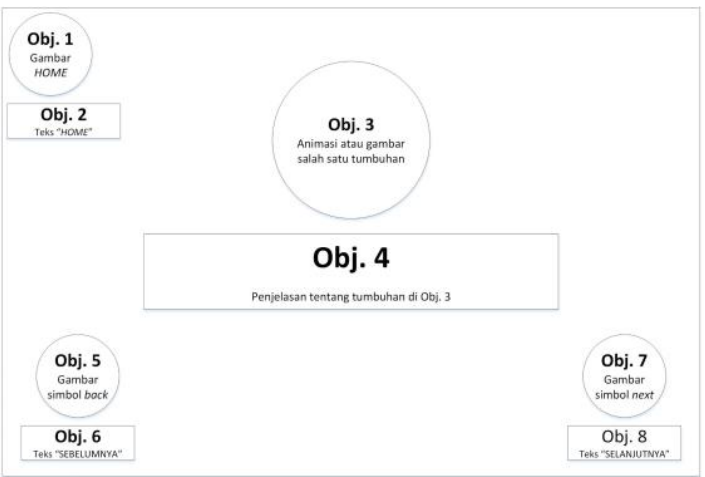

Gambar 8. Tampilan Isi Menu Tumbuhan

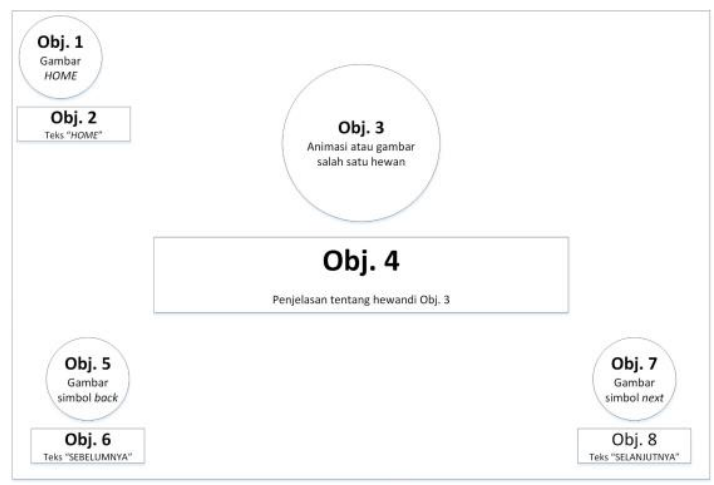

Gambar 9. Tampilan Isi Menu Hewan

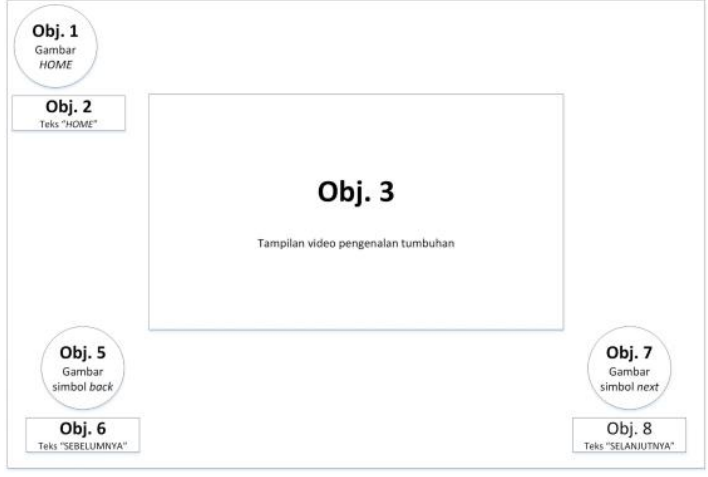

Gambar 10. Tampilan Video Pengenalan Tumbuhan

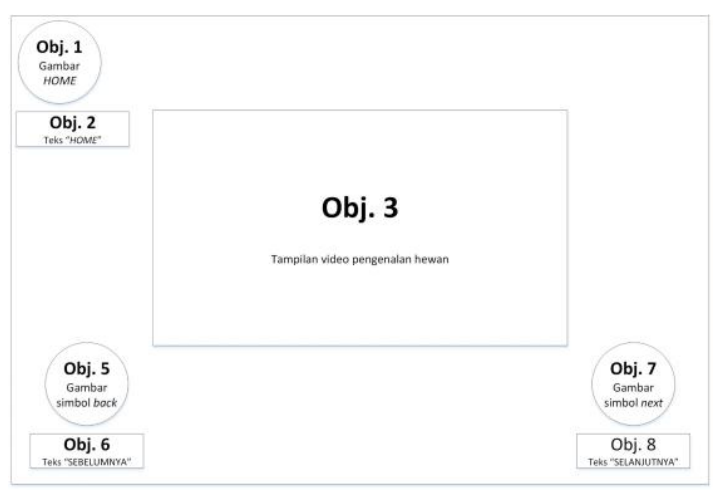

Gambar 11. Tampilan Video Pengenalan Hewan

Hasil desain aplikasi pembelajaran berbasis mobile learning ini kemudian ditunjukkan kepada 2 orang ahli media, 2 orang ahli materi, dan 10 orang guru untuk divalidasi. Semua validator kemudian mengisi angket yang telah disediakan. Angket yang digunakan dalm bentuk checklist $(\sqrt{ })$ dengan menggunakan skala Likert dimana setiap jawaban item instrumen mempunyai gradasi dari sangat positif sampai sangat negatif, untuk keperluan analisis kuantitatif, maka jawaban itu dapat diberi skor (Sugiyono, 2015). Skala angket dapat dilihat pada tabel 1.

Tabel 1. Skala Likert dengan 5 Skala

\begin{tabular}{lc}
\hline \multicolumn{1}{c}{ Pernyataan } & Skor \\
\hline Sangat Setuju (SS) & 5 \\
Setuju (S) & 4 \\
Kurang Setuju (KS) & 3 \\
Tidak Setuju (TS) & 2 \\
Sangat Tidak Setuju (STS) & 1 \\
\hline
\end{tabular}

Data hasil validasi kemudian dianalisis dengan menghitung rata-rata jawaban berdasarkan skor setiap jawaban dari 
responden. Berdasarkan skor yang telah ditetapkan dapat dihitung sebagai berikut:

Skor total $=($ JSS x 5) $+($ JS x 4) $+($ JKS x

$$
3)+(\text { JTS } \times 2)+(\text { JSTS } \times 1)
$$

Keterangan:

JSS = Jumlah responden menjawab Sangat Setuju

$\mathrm{JS}=$ Jumlah responden menjawab Setuju

JRR = Jumlah responden menjawab Kurang Setuju

JRS $=$ Jumlah responden menjawab Tidak

Setuju

JSTS = Jumlah responden menjawab Sangat Tidak Setuju

Setelah skor total diperoleh kemudian mencari persentase skor untuk mendapatkan interpretasi hasil pengujian menggunakan rumus:

$$
P_{\text {skor }}=\frac{\text { Skortotal }}{\text { ixr } 5} \times 100 \%
$$

Keterangan:

Skor $_{\text {total }}=$ Skor total hasil responden menjawab

$i=$ Jumlah Pertanyaan

$r \quad=$ Jumlah Responden

Data yang diperoleh kemudian dikonversi berdasarkan tabel kategori kelayakan menurut (Guritno \& Sudaryono, 2011) seperti pada tabel 2 berikut:

Tabel 2. Kategori Kelayakan

\begin{tabular}{cc}
\hline Persentase Skor & Interpretasi \\
\hline $0 \%-20 \%$ & Sangat Tidak Layak \\
$21 \%-40 \%$ & Tidak Layak \\
$41 \%-60 \%$ & Cukup Layak \\
$61 \%-80 \%$ & Layak \\
$81 \%-100 \%$ & Sangat Layak \\
\hline
\end{tabular}

Ahli media yang berjumlah 2 orang diberikan angket dengan jumlah pertanyaan sebanyak 36 pertanyaan yang menilai 4 aspek yaitu aplikasi, navigasi, tampilan visual, dan isi dengan masing-masing aspek terdapat indikator penilaian. Angket yang diuji sudah melewati proses validasi sebelumnya. Hasil perhitungan validasi ahli media diberikan skor seperti terlihat pada tabel 3 .

Hasil perhitungan persentase kelayakan ahli media adalah $89,44 \%$. Nilai kuantitatif yang didapatkan kemudian dikonversikan menjadi nilai kualitatif berdasarkan kategori kelayakan di tabel 2, dan hasil pengujian ahli media yang didapatkan adalah dengan interpretasi "sangat layak".

Tabel 3. Perhitungan Skor Validasi Ahli Media

\begin{tabular}{cccc}
\hline Pilihan & Jumlah & Skor & $\begin{array}{c}\text { Jumlah } \\
\text { x Skor }\end{array}$ \\
\hline SS & 35 & 5 & 175 \\
S & 36 & 4 & 144 \\
KS & 1 & 3 & 3 \\
TS & 0 & 2 & 0 \\
STS & 0 & 1 & 0 \\
& Skor Total & & 322 \\
\hline
\end{tabular}

Keterangan tabel:

Pilihan $=$ jenis pernyataan berdasarkan skala Likert

Jumlah $=$ hasil penjumlahan dari pilihan semua responden untuk setiap pernyataan

skor $=$ skor berdasarkan skala Likert dengan 5 Skala

Berdasarkan tabel 3 dapat diperoleh persentase kelayakan hasil validasi ahli media sebagai berikut:

Skor maksimal $=$ Jumlah pertanyaan $\mathrm{x}$ Jumlah responden $\mathrm{x} 5$

$=36 \times 2 \times 5$

$=360$

Persentase Kelayakan (\%)

$$
\begin{aligned}
& =\frac{\text { Skor total }}{\text { Skor maksimal }} \times 100 \% \\
& =\frac{322}{360} \times 100 \% \\
& =89,44 \%
\end{aligned}
$$

Ahli materi yang berjumlah 2 orang diberikan angket yang disusun berdasarkan standarisasi model Alessi dan Trollip (Yogiyatno \& Sofyan, 2013) dengan jumlah pertanyaan sebanyak 38 pertanyaan yang menilai 5 aspek yaitu kesesuaian dengan tujuan pembelajaran, struktur materi, keakuratan isi materi, penggunaan bahasa, dan pemanfaatan dengan masing-masing aspek terdapat indikator penilaian. Angket yang diuji sudah melewati proses validasi sebelumnya. Hasil perhitungan validasi ahli media diberikan skor seperti terlihat pada tabel 4 . 
Tabel 4. Perhitungan Skor Validasi Ahli Materi

\begin{tabular}{cccc}
\hline Pilihan & Jumlah & Skor & $\begin{array}{c}\text { Jumlah } \\
\text { x Skor }\end{array}$ \\
\hline SS & 45 & 5 & 225 \\
S & 32 & 4 & 128 \\
KS & 0 & 3 & 0 \\
TS & 0 & 2 & 0 \\
STS & 0 & 1 & 0 \\
& Skor Total & & 353 \\
\hline
\end{tabular}

Keterangan tabel:

Pilihan $=$ jenis pernyataan berdasarkan skala Likert

Jumlah $=$ hasil penjumlahan dari pilihan semua responden untuk setiap pernyataan

skor $=$ skor berdasarkan skala Likert dengan 5 Skala

Berdasarkan tabel 4 dapat diperoleh persentase kelayakan hasil validasi ahli materi sebagai berikut:

Skor maksimal $=$ Jumlah pertanyaan $\mathrm{x}$ Jumlah responden $\mathrm{x} 5$

$$
=38 \times 2 \times 5
$$$$
=380
$$

Persentase Kelayakan (\%)

$$
\begin{aligned}
& =\frac{\text { Skor total }}{\text { Skor maksimal }} \times 100 \% \\
& =\frac{359}{380} \times 100 \% \\
& =92,89 \%
\end{aligned}
$$

Hasil perhitungan persentase kelayakan ahli materi adalah $92,89 \%$. Nilai kuantitatif yang didapatkan kemudian dikonversikan menjadi nilai kualitatif berdasarkan kategori kelayakan di tabel 2 , dan hasil pengujian ahli media yang didapatkan adalah dengan interpretasi "sangat layak".

Selanjutnya desain media pembelajaran berbasis mobile learning ini ditunjukkan kepada guru-guru yang mengajar di SD Negeri 2 Tomohon sebanyak 10 guru. Guru-guru diberikan angket yang mengadopsi pada USE Questionare (Lund, 2001). Angket berisi 30 pertanyaan dengan 4 aspek penilaian yaitu usefulness, easy of use, ease of learning, dan satisfaction. Hasil perhitungan validasi dari guru-guru diberikan skor yang dapat dilihat pada tabel 5 .
Tabel 5. Perhitungan Skor Validasi Guru

\begin{tabular}{cccc}
\hline Pilihan & Jumlah & Skor & $\begin{array}{c}\text { Jumlah } \mathbf{x} \\
\text { Skor }\end{array}$ \\
\hline SS & 200 & 5 & 1000 \\
S & 100 & 4 & 400 \\
KS & 0 & 3 & 0 \\
TS & 0 & 2 & 0 \\
STS & 0 & 1 & 0 \\
& Skor Total & & 1400 \\
\hline
\end{tabular}

Keterangan tabel:

Pilihan $=$ jenis pernyataan berdasarkan skala Likert

Jumlah $=$ hasil penjumlahan dari pilihan semua responden untuk setiap pernyataan

skor $=$ skor berdasarkan skala Likert dengan 5 Skala

Berdasarkan tabel 5 dapat diperoleh persentase kelayakan hasil uji kelas kecil adalah sebagai berikut:

Skor maksimal $=$ Jumlah pertanyaan $\mathrm{x}$ Jumlah responden $\times 5$

$=30 \times 10 \times 5$

$$
=1500
$$

Persentase Kelayakan (\%)

$$
\begin{aligned}
& =\frac{\text { Skor total }}{\text { Skor maksimal }} \times 100 \% \\
& =\frac{1400}{1500} \times 100 \% \\
& =93,33 \%
\end{aligned}
$$

Hasil perhitungan persentase kelayakan uji kelas kecil adalah 93,33\%. Nilai kuantitatif yang didapatkan kemudian dikonversikan menjadi nilai kualitatif berdasarkan kategori kelayakan di tabel 2, dan hasil pengujian ahli media yang didapatkan adalah dengan interpretasi "sangat layak".

\section{KESIMPULAN}

Desain yang dibuat telah divalidasi oleh ahli media, ahli materi dan guru pengajar kemudian diperolah hasil perhitungan persentase kelayakan. Hasil validasi ahli media diperoleh persetase kelayakan sebesar $89,44 \%$, hasil validasi ahli materi diperoleh persetase kelayakan sebesar $92,89 \%$, dan hasil validasi dari guru-guru diperoleh persetase kelayakan sebesar 93,3\%. Desain media pembelajaran berbasis Mobile Learning (M-Learning) ini layak digunakan pada siswa sekolah dasar 


\section{DAFTAR PUSTAKA}

Donnell, A. O., \& A.O. Donnell. 2014. Using M-learning as a Means to Promote Selfdirection and Engagement in Apprenticeship Theoretical Lessons apprenticeship theoretical lessons. Irish Journal of Academic Practice, 3(1): 10 30. https://doi.org/10.21427/D75B06.

Guritno, \& R. Sudaryono. 2011. Theory and Application of IT RESEARCH: Metodologi Penelitian Teknologi Informasi. Andi Offset, Yogyakarta.

Lund, A. M. 2001. Measuring usability with the USE questionnaire. Usability

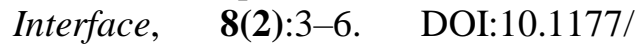
1078087402250360.

Munir. 2013. Multimedia, Konsep Aplikasi Multimedia. Alfabeta, Bandung.

Pressman, R. S. 2001. Software Engineering A Practitioner's Approach, $5^{\text {th }}$ Edition. McGraw-Hill Companies, New York.

Rosa, A.S., \& M. Shalahuddin. 2015. Rekayasa Perangkat Lunak Terstruktur dan Berorientasi Objek. Informatika, Bandung.

Sonego, A.H.S., L.R. MacHado, C.A.W. Torrezzan \& P.A. Behar. 2016. Mobile learning: Pedagogical strategies for using applications in the classroom. Proceedings of the $12^{\text {th }}$ International Conference on Mobile Learning 2016: 28-34.
Sugiyono. 2015. Metode Penelitian dan Pengembangan Research and Development. Alfabeta, Bandung.

Yogiyatno, W., \& H. Sofyan. 2013. Pengembangan multimedia interaktif kompetensi dasar mengoperasikan software basis data untuk SMK Negeri 1 Seyegan. Jurnal Pendidikan Vokasi, 3(3):391-404. DOI:10.21831/jpv. v3i3.1851.

Yuniati, L. 2012. Pengembangan Media Pembelajaran Mobile Learning Efek Doppler Sebagai Alat Bantu Dalam Pembelajaran Fisika Yang Menyenangkan. Jurnal Penelitian Pembelajaran Fisika, 2(2):92-101. DOI:10.26877/jp2f.v2i2/septembe.130.

Yusuf, M. O. (2005). Information and communication technology and education: Analysing the Nigerian national policy for information technology. International Education Journal, 6(3): 316-321. 